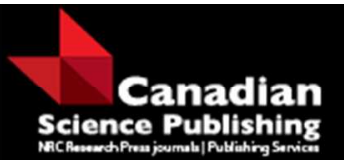

Canadian Journal of Forest Research

Revue canadienne de recherche forestière

\title{
Modelling the variability of density and bending properties of Norway spruce structural timber
}

\begin{tabular}{|r|l|}
\hline Journal: & Canadian Journal of Forest Research \\
\hline Manuscript ID & cjfr-2016-0022.R2 \\
\hline Manuscript Type: & Article \\
\hline Date Submitted by the Author: & $10-$ May-2016 \\
\hline Kemplete List of Authors: & $\begin{array}{l}\text { Fischer, Carolin; Norwegian University of Life Sciences, Ecology and } \\
\text { Natural Resource Management } \\
\text { Vestøl, Geir; Norges miljo- og biovitenskapelige universitet, Ecology and } \\
\text { Natural Resource Management } \\
\text { Nøibø, Olav; Norges miljo- og biovitenskapelige universitet, Ecology and }\end{array}$ \\
\hline \multicolumn{2}{|c|}{ MOE, MOR, density, geographical data, forest inventory data } \\
\hline
\end{tabular}

SCHOLARONE $^{\text {Im }}$

Manuscripts 
1 Modelling the variability of density and bending properties of 2 Norway spruce structural timber

4 Carolin Fischer, Norwegian University of Life Sciences, Department of Ecology and Natural 5 Resource Management, P.O. Box 5003, N-1432 As, Norway.

$6 \quad$ E-mail: carolin.fischer@nmbu.no. Phone: +47 67231764

7

8 Geir I. Vestøl, Norwegian University of Life Sciences, Department of Ecology and Natural

9 Resource Management, P.O. Box 5003, N-1432 As, Norway.

10 E-mail: geir.vestol@nmbu.no. Phone: +47 67231736

11

12

Olav Høibø, Norwegian University of Life Sciences, Department of Ecology and Natural

13 Resource Management, P.O. Box 5003, N-1432 As, Norway.

14 E-mail: olav.hoibo@nmbu.no. Phone: +47 41251371

15

16 


\section{Abstract}

2 Density, modulus of elasticity (MOE) and bending strength (MOR) are important properties of 3 structural timber, and knowledge about the variability of these properties is important to make

4 efficient use of the timber. In order to utilize such information in the production of structural

5 timber, the information must be available before sawing. This study presents models describing

6 the variability of density and bending properties of Norway spruce boards within individual

7 trees, as well as among trees and stands, based on geographical data and forest inventory data

8 including external tree measurements.

10 The models were based on 1551 boards from 17 sites in Southern Norway, Eastern Norway and

11 Trøndelag. Important variables describing variation in density, MOE and MOR between sites

12 were site index and elevation. For density, latitude gave additional information. Age, DBH and

13 longitudinal position within the tree were the most important variables at the tree level. The

14 models explained major parts of the site variance of all properties, and for MOR they explained a

15 substantial part of the variance due to trees. In addition to being used for predicting the

16 properties of structural timber from current forest resources, the models also provide information

17 that can be used to predict the effects of silviculture on timber properties in future forest stands.

19 Keywords: MOE, MOR, density, geographical data, forest inventory data 


\section{Introduction}

2 For species in Europe, density, modulus of elasticity (MOE) and bending strength (MOR) vary

3 significantly both between regions (Ranta-Maunus 2009) and within regions (Foslie 1985, Foslie

4 and Moen 1968, Lackner and Foslie 1988, Nagoda 1985, Hautamäki et al. 2013, Moore et al.

5 2013, Gardiner et al. 2011). The large variation found between sites, between trees within sites

6 and within single trees (Zobel and van Buijtenen 1989, Vestøl et al. 2012, Høibø et al. 2014)

7 makes individual strength grading of each single board crucial for achieving effective use of

8 timber as a structural material.

10 Today most sawmills use machine strength grading, which is more accurate than visual grading.

11 This has led to greater yields of higher grades, thus increasing the competitiveness of timber as a

12 structural material (Ranta-Maunus 2009). However, most of the strength grading machines used

13 account for only a relatively small part of the total variation. Methods for improved sorting and

14 grading are therefore needed. Predictions of properties based on forest inventory data might be

15 used together with data from strength grading machines to make timber grading more accurate

16 (Stapel and van de Kuilen 2013, Høibø et al. 2014, Lukacevic et al. 2015) and grade yield higher.

17 Incorporating information on the variation between and within trees also makes more optimal

18 crosscutting possible (Høibø et al. 2014).

20 Wood density is itself an important timber property (Standard Norge 2009), but it is also widely

21 used as an indicator of timber qualities due to its positive correlations with most mechanical

22 properties. For Norway spruce (Picea abies L. Karst), density is negatively correlated with

23 growth rate (Persson 1975), leading to lower density for more dominant trees (Pape 1999). On 
1 the other hand, density has been found to be positively correlated with temperature sum

2 (Wilhelmsson 2001), which fits well with Høibø (1991), who found a higher density at the same

3 annual ring width in material from the region around Oslo (latitude: $59^{\circ} \mathrm{N}$ ) than Nagoda (1985)

4 found for material from further north (latitude: $65.5-69.5^{\circ} \mathrm{N}$ ).

6 For planted Norway spruce trees, density was found to decrease across the first three to five

7 annual rings, and then slightly increase further throughout the mature wood (Kuçera 1994).

8 Kliger et al. (1998) found the same pattern. The longitudinal variation in density shows divergent 9 patterns. While Kuçera (1994) found an increase in density with an increase in the height in the 10 tree for a given ring number from the pith, Atmer and Thörnqvist (1982) found a slight decrease

11 from the ground up to $75 \%$ of the stem height. Hakkila (1996) found a slight decrease in density

12 up to $50 \%$ of the stem height, followed by an increase in the upper half. Repola (2006)

13 confirmed this. Høibø et al. (2014) found density to increase with height on rich sites, while it 14 was opposite on poor sites.

16 Knot diameter is another very important stem characteristic that greatly influences timber 17 strength (Kellogg and Kennedy 1986). Mäkinen and Colin (1998) found an increase in branch 18 diameter with increasing diameter at breast height and crown length for Scots pine (Pinus 19 sylvestris L.). Knot size has been shown to increase with diameter growth for Norway spruce 20 (Vestøl and Høibø 2001), leading to a decrease in bending properties (MOE and MOR) (Høibø 21 1991). Colin and Houllier (1991) found knot diameter to increase with longitudinal distance from

22 the ground, followed by a decrease closer to the top. This pattern was confirmed for several 23 species, such as Scots pine (Mäkinen and Colin 1998), Douglas fir (Pseudotsuga menziesii 
1 (Mirb.) Franco) (Maguire et al. 1999), Sitka spruce (Auty et al. 2012) and Norway spruce

2 (Mäkinen et al. 1998).

4 Since structural timber has to fulfill requirements for density, MOE and MOR (Standard Norge 5 2009), deep knowledge about the relationships between the properties is important for the design 6 of economic and reliable timber structures (Steiger and Arnold 2009). Høibø et al. (2014) found

7 that detailed tree- and log-level information can be used to improve grading accuracy. The

8 relationship between density and bending properties varies considerably among trees, stands and

9 regions, but the importance of these properties also varies with use. Due to the negative effect of

10 the temperature sum on density (Wilhelmsson et al. 2002), we expect to find a negative effect of

11 latitude and elevation on density, leading to a negative effect on MOE. The corresponding effects

12 on MOR may be smaller, given that MOR has been found to be less affected by wood density

13 and more by knot diameter (Vestøl et al. 2012). As described above, the longitudinal variation in

14 density shows divergent patterns in Norway spruce. According to Høibø et al. (2014), it adds to

15 the effect of knot size on poor sites but counteracts the effect of knot size on more fertile sites.

16 The total effect of longitudinal position can therefore be expected to be different for MOE and

17 MOR, and may also depend on site index.

19 Models describing the properties of structural timber based on site and tree variables have been

20 developed for some species. Lei et al. (2005) and Liu et al. (2007) have developed models

21 predicting the strength and stiffness of black spruce timber on the basis of tree characteristics.

22 Similar models have been developed for Scots pine logs from Norway (Høibø and Vestøl, 2010).

23 The models show that tree and stand level characteristics predict strength and stiffness fairly 
1 well. Lei et al. (2005) showed that stem taper, DBH and crown length are important variables

2 when modelling MOE and MOR based on only stand and tree characteristics. Liu et al. (2007)

3 showed that the tree and stand characteristics that best predicted the bending stiffness of

4 naturally grown black spruce were DBH, crown length, stem taper and stand density. Haartveit

5 and Flæte (2002) found that MOE and MOR negatively correlate with stem taper and crown

6 length. Øvrum (2013) found the average ratio of tree height to DBH to be a good site indicator

7 for the grade yield of structural timber, probably due to its correlation with crown ratio.

8 Hautamäki et al. (2013) developed models for Norway spruce from Finland and Russia. They

9 found that MOE is the best predictor for MOR, followed by ring width, wood density and knot

10 area ratio, while for MOE, density was the best single predictor, followed by ring width and

11 number of annual rings.

13 Models describing the properties of structural Norway spruce sawn timber from Norway have so

14 far been limited to certain regions, and they do not represent the wide range of elevations and

15 latitudes at which this species occurs in Norway. This means that the models cannot be expected

16 to account for differences in structural timber properties due to climate. As far as we know,

17 studies considering such effects in models predicting structural wood properties are limited. The

18 aim of this study was therefore to develop models that describe the variability of density and

19 bending properties of Norway spruce structural timber from forests throughout the most

20 important procurement areas for sawmills in Norway. The models should also provide a better

21 understanding of how silviculture affects the properties of structural timber from different

22 regions. 


\section{Material and methods}

2 The study was based on timber from 17 sites in Southern Norway, Eastern Norway, and

3 Trøndelag (Figure 1). The sites numbered 1-14 have been described by Vestøl et al. (2016), and

4 sites 15, 16 and 17 were used in an earlier study published by Høibø et al. (2014). The material

5 reflects large variations in latitude, elevation and site index, and represents the growing

6 conditions for spruce in Norway. The sites were randomly divided into 11 modelling sites and

7 six validation sites. The site-level data were elevation (Elev in m.a.s.), latitude (Lat), basal area

8 (BA in $\mathrm{m}^{2} \mathrm{ha}^{-1}$ ) and site index (SI in $\mathrm{m}$ ). Site index, defined as dominant height at age 40 (Tveite

9 1977), was calculated from age at breast height and the height of the three largest trees sampled

10 from each site. For sites 15, 16 and 17, the site indices were obtained from forest inventory plans

11 and checked for height and age at stump height for the three largest trees sampled, taking the

12 estimated number of years from butt end to breast height into account. The site-level and forest

13 inventory data for each site is presented in Table 1.

At each site, diameter at breast height (DBH in $\mathrm{mm}$ ) was recorded for all trees within a selected area. Trees with a DBH larger than $20 \mathrm{~cm}$ were classified into five diameter classes with an equal

17 number of trees in each class. Three trees were randomly selected from each diameter class in order to obtain a representative sample for the trees with a DBH greater than $20 \mathrm{~cm}$.

The tree variables measured were $\mathrm{DBH}$, age at stump height (Age in years), tree height (H in

$21 \mathrm{dm})$, height to the whorl where live branches covered half of the circumference $\left(\mathrm{KH}_{180} \mathrm{in} \mathrm{dm}\right)$

22 and height to the whorl where live branches covered the whole circumference $\left(\mathrm{KH}_{360}\right.$ in $\left.\mathrm{dm}\right)$.

23 Other tree-level variables that were calculated from these were $\mathrm{DBH} /$ Age $(\mathrm{mm}), \mathrm{H} / \mathrm{DBH}(\mathrm{dm}$ 
$\left.1 \mathrm{~mm}^{-1}\right)$ and relative $\mathrm{DBH}\left(\mathrm{DBH}_{\mathrm{rel}}\right)$. The latter was defined as the ratio of individual tree $\mathrm{DBH}$ to

2 mean DBH of the site. All variables are presented in Table 2, and correlations are presented in 3 Table 3.

4

5 The trees were cut into logs of $3.6 \mathrm{~m}, 4.2 \mathrm{~m}$ and $4.6 \mathrm{~m}$, depending on the top diameter. The

6 minimum top diameter was set to $15 \mathrm{~cm}$, to make sure that it was possible to produce at least two

7 boards with a cross-section of $38 \times 100 \mathrm{~mm}$. The logs were sawn, without shortening the length,

8 into boards of $38 \times 100 \mathrm{~mm}, 50 \times 100 \mathrm{~mm}, 50 \times 150 \mathrm{~mm}, 50 \times 200 \mathrm{~mm}$ and $50 \times 225 \mathrm{~mm}$,

9 depending on the top diameter.

11 The boards were conditioned in a climate with $65 \% \mathrm{RH}$ and $20{ }^{\circ} \mathrm{C}$ for at least five weeks to a

12 stable moisture content before testing. MOE and MOR were calculated from the results of four-

13 point bending. The test was done according to the requirements in EN 408 (Standard Norge

14 2010b). The critical section, i.e. the position at which failure was expected, was located. The

15 boards were shortened to 20 times the nominal height (nominal board width is defined as

16 nominal cross-sectional board height according to EN 408 (Standard Norge 2010b)) with the

17 critical section located in the middle two-thirds of the board. To ensure the best possible

18 longitudinal range within the tree, the upper part of boards from the upper log was chosen if the

19 quality was homogenous along the board. The boards from sites 15, 16 and 17 were, depending

20 on which log they had been taken from, located systematically within the log, boards from the

21 butt log were taken from the end closest to the stump, whereas boards from the other logs were

22 taken from the end closest to the top (Høibø et al. 2014). The relative longitudinal position 
1 (LP rel $)$ was defined as the ratio of the longitudinal within-tree position of the center of the board

2 to the height of the tree.

4 Density and moisture content were determined from cross-sectional specimens of clear wood 5 taken as close to the failure point as possible. The moisture content of the material varied from $68.9 \%$ to $17.4 \%$, with an average of $13.6 \%$. According to EN 384 (Standard Norge 2010a),

7 density was adjusted by $0.5 \%$ for each percentage point deviation from $12 \%$ moisture content, 8 and MOE was adjusted by $1 \%$ for each percentage point deviation from $12 \%$ moisture content.

9 Even though EN 384 (Standard Norge 2010a) does not prescribe an adjustment of MOR for moisture content, MOR was adjusted as well using the same correction factor as used for MOE.

11 All adjustments were made on single observations. The number of observations, the minimum, 12 maximum and mean values, and the standard deviations of density and bending properties are 13 presented in Table 4.

Statistical analysis

16 Linear mixed models were used to analyse variations in density, MOR and MOE. Random

17 variance was divided into site variance, tree variance and residual variance:

$21 \mathrm{Y}$ represents density $\left(\rho_{12}\right), \mathrm{MOE}_{12}$ or $\mathrm{MOR}_{12}, \mu$ represents the mean in variance component 22 analyses or intercept in covariate models, and $f(A, B, \ldots)$ represents the fixed-effects part of the 23 model. $S_{i}$ represents the random site effect, $T_{j}\left(S_{i}\right)$ represents the nested random tree effect and $e$ 
1 represents the residuals, describing the within-tree variance. The random effects were assumed to

2 be normally distributed with a mean of zero and variances of $\sigma_{\mathrm{S}}{ }^{2}, \sigma_{\mathrm{T}}{ }^{2}$ and $\sigma_{\mathrm{e}}{ }^{2}$, respectively.

4 The modelling was done in two steps. The first models, including only random effects,

5 describing the between-site variance, between-tree variance (nested under site) and residual

6 variance (within-tree variance), were calculated for each property. In the second step, site and

7 tree variables (Table 2) and possible interactions were added to the models. A variance inflation

8 factor (VIF) was used to check for multicollinearity within the models, and covariates were

9 rejected if the VIF was larger than 5. The Akaike information criterion (AICc) (Hurvich and Tsai

10 1989) was used to assess the relative goodness of fit of the models. The models were evaluated

11 by means of coefficient of determination $\left(\mathrm{R}^{2}\right)$ and root mean square error (RMSE) of the fixed-

12 effects part of the model. The linear mixed models were calculated using the restricted maximum

13 likelihood method (REML) in JMP software (version 11.0; SAS Institute Inc., Cary, North

14 Carolina) following Littell et al. (2006). Fixed-effects variables were included in the models if

15 the probability of a type I error was smaller than 0.05 .

16

17 The covariate models were tested on the validation material and were evaluated by coefficient of

18 determination, residual mean square error, and mean deviance and deviance for individual sites.

19 The $\mathrm{R}^{2}$ and RMSE values were calculated from the residuals, i.e. the difference between

20 measured density, $\mathrm{MOE}_{12}$ and $\mathrm{MOR}_{12}$ and the predicted values when using the developed models

21 on the validation material.

22 Results 
1

2 The density model (Model 1, Table 5) describes negative effects of elevation, latitude and site

3 index on density. These variables describe differences among the sites only. However, the model

4 also includes a negative effect of DBH and a positive effect of age, describing both variances due

5 to sites and variances due to trees within the site. The effect of longitudinal position varied from

6 a steep increase to a steep decrease (line b and c, Figure 2), but for an average tree from and

7 average stand the model describes a negligible vertical increase in density (line a, Figure 2). The

8 differences in longitudinal variation are described by positive interactions between longitudinal

9 position $\left(\mathrm{LP}_{\text {rel }}\right)$ and site index, elevation and $\mathrm{DBH}$, respectively, and a negative interaction with

crown height $\left(\mathrm{KH}_{180}\right)$. The effect of $\mathrm{KH}_{180}$ alone was not significant; we have nevertheless

chosen to include this lower-level variable in the model. The interactions describe a steeper increase in density with an increased $\mathrm{LP}_{\text {rel }}$ for higher values of site index, elevation and DBH and lower values of $\mathrm{KH}_{180}$ (Table 5). At lower elevations, where the site index range is large, the interactions predict the largest vertical decrease in small trees with high values of $\mathrm{KH}_{180}$ from low site indices (line c, Figure 2), while there is a negligible increase for big trees with low $\mathrm{KH}_{180}$. For high site indices at low elevations the model predicts a vertical increase in density for big trees with low $\mathrm{KH}_{180}$ but a negligible longitudinal variation for small trees with high $\mathrm{KH}_{180}$. Site index is limited by elevation, but with a high but realistic site index at high elevation the model describes the largest vertical increase in density for trees with low $\mathrm{KH}_{180}$ and large $\mathrm{DBH}$ (line b, Figure 2). For small trees, the longitudinal variation is negligible. Altogether, the interaction effects describe much larger variation for density in the lower part of the stems than in the upper part (Figure 2) when comparing timber from trees with different values for the variables interacting with $\mathrm{LP}_{\text {rel }}$. 
2 The fixed-effects part of the model reduced the total variance by $56.7 \%$, and the RMSE was

$3 \quad 34.5 \mathrm{~kg} \mathrm{~m}^{-3}$. Compared to the variance component model (Table 6), the model showed a $93.4 \%$

4 lower variance due to site, $15.4 \%$ lower variance due to trees, and a $19.7 \%$ lower residual

5 variance. When using the model on the validation data, the predicted values were on average 0.1

$6 \mathrm{~kg} \mathrm{~m}^{-3}$ higher than the observed values. The model reduced total variance by $48.9 \%$, and RMSE

7 was $38.6 \mathrm{~kg} \mathrm{~m}^{-3}$. The residual of site means was positive for three sites and negative for the other

8 three, and the largest negative deviation of a site mean was $12.1 \mathrm{~kg} \mathrm{~m}^{-3}$ for site 13 . The effect of

9 the interaction between $\mathrm{LP}_{\text {rel }}$ and $\mathrm{KH}_{180}$ was minor, and an alternative model without this effect

10 was estimated to check for possible over-parameterization. The reduced model had a higher AIC

11 (9344 vs. 9335) and a slightly lower R-square $\left(r^{2}=0.563\right.$ vs. 0.567$)$ in the modelling step, but for

12 the validation data the difference was larger $\left(r^{2}=0.462\right.$ vs. 0.489$)$.

\section{MOE model}

15 The model describes a negative main effect of elevation on $\mathrm{MOE}_{12}$ (Model 2, Table 5), while the 16 effect of site index alone was not significant. Like the density model, the $\mathrm{MOE}_{12}$ model includes

17 a negative effect of DBH and a positive effect of age, both describing variance due to trees and

18 variance due to site. The model includes a negative main effect of relative longitudinal position, 19 describing a slight vertical decrease in $\mathrm{MOE}_{12}$ (line a, Figure 3). The effect of longitudinal 20 position depends both on elevation and on site index, and is revealed by its positive interactions 21 with both. The interaction effect with elevation describes a stronger effect of elevation on timber

22 from butt logs than on timber from upper logs. The interaction between longitudinal position and 23 site index reduces the vertical decrease in $\mathrm{MOE}_{12}$ with increasing site index. Since site index is 
1 limited by elevation, the effect of the interaction with site index is limited at high elevations. The

2 model predicts a negligible effect from longitudinal position in trees at a higher elevation when

3 using high but realistic site indices (line b, Figure 3). At lower elevations, where the site index

4 range is larger, the interaction between site index and $L P_{\text {rel }}$ predicts a vertical decrease of $\mathrm{MOE}_{12}$, 5 with the strongest effect in trees from low site indices (line c, Figure 3).

7 The fixed-effects part of the $\mathrm{MOE}_{12}$ model reduced the overall variance by $42.1 \%$, and the

8 RMSE was $2.14 \mathrm{kN} \mathrm{mm}^{-2}$ (Model 2, Table 5). Compared to the variance component model

9 (Table 6), the model showed $89.3 \%$ lower variance due to site, $25.9 \%$ lower variance due to trees

10 and $4.1 \%$ lower residual variance. When using the model on the validation data, the predicted

11 values were on average $0.49 \mathrm{kN} \mathrm{mm}^{-2}$ higher than the observed values. The model was able to

12 account for $42.4 \%$ of the variance in the validation material, and the RMSE was $2.24 \mathrm{kN} \mathrm{mm}^{-2}$.

13 The residual of site means was negative for five sites and positive for only one, and the greatest

14 deviance of site means was found for site 13 with $-1.66 \mathrm{kN} \mathrm{mm}^{-2}$ and for site 3 with $-1.09 \mathrm{kN}$

$15 \mathrm{~mm}^{-2}$.

16

17 MOR model

18 The $\mathrm{MOR}_{12}$ model (Model 3, Table 5) describes a negative effect of elevation on $\mathrm{MOR}_{12}$, while

19 the effects of latitude and site index were not significant and are therefore not included in the

20 model. Even though the parameter estimate is greater in the $\mathrm{MOR}_{12}$ model than in the $\mathrm{MOE}_{12}$

21 model (Table 5), the relative effect of elevation was smaller on $\mathrm{MOR}_{12}$ than on $\mathrm{MOE}_{12}$. As for

22 the other models, the $\mathrm{MOR}_{12}$ model also includes a negative effect of $\mathrm{DBH}$ and a positive effect

23 of age. These variables describe both variance due to trees and variance due to site. The model 
1 also includes a negative effect of longitudinal position, describing a vertical decrease in $\mathrm{MOR}_{12}$,

2 but no interactions between longitudinal position and other variables. Figure 4 shows the

3 negative effects of longitudinal position and elevation for trees with average DBH and Age.

4 There was a significant negative interaction among longitudinal position, site index and $\mathrm{DBH}$,

5 but when checking this three-way interaction effect for possible over-parameterization, the

6 model where the interaction effect was included was found to have a higher AICc (7071 vs.

7 7066). The three-way interaction effect has therefore not been included in the model presented.

9 The fixed-effects part of the model reduced the total variance by $35.2 \%$, and the RMSE was

$1010.3 \mathrm{~N} \mathrm{~mm}^{-2}$. Compared to the variance component model (Table 6), the model showed $95.3 \%$

11 lower variance due to site, $50.7 \%$ lower variance due to trees, and $2.0 \%$ lower residual variance.

12 When using the model on the validation data, the predicted values were on average $1.97 \mathrm{~N} \mathrm{~mm}^{-2}$

13 higher than the observed values. The model reduced the overall variance in the validation data by

$1433.9 \%$, and RMSE was $10.4 \mathrm{~N} \mathrm{~mm}^{-2}$. The residual of site means was negative for four of the six

15 sites and positive for two, and the greatest deviations of site mean were $-3.84 \mathrm{~N} \mathrm{~mm}^{-2}$ for site 13

16 and $-7.32 \mathrm{~N} \mathrm{~mm}^{-2}$ for site 3 .

17

\section{Discussion}

19 Both the negative effect of site index and the combined effect of DBH and age on density

20 (Model 1, Table 5) correspond with the negative effect of annual ring width on density found in

21 many studies of Norway spruce (Kollmann and Coté 1968, Pape 1999 and Wilhelmsson et al.

22 2002).

23 
1 The negative effects of elevation and latitude on density, after adjusting for site index, DBH and

2 age (Model 1, Table 5), correspond with results reported by Wilhelmsson et al. (2002), who

3 found that density increases with temperature sum. They also correspond with results reported by

4 Gindl et al. (2000), who found a positive correlation between within-ring maximum density and

5 temperature in August-September, which shows that the autumn temperature is important for

6 density. A similar result was reported by Høibø (1991), who found higher density for material

7 from the Oslo region $\left(59^{\circ} \mathrm{N}\right.$ latitude) compared to material from the latitudes $65.5-69.5^{\circ} \mathrm{N}$ that

8 was studied by Nagoda (1985). The positive effect of age on density and MOE is related to the

9 negative effect of age on annual ring width (Wilhelmsson et al. 2002). The negative effect of

10 annual ring width on density is related to a smaller proportion of latewood (Jyske et al. 2008).

12 The between-sites variation in bending properties followed the variation in density, and the 13 effects of DBH, age and elevation were significant for both MOE (Model 2, Table 5) and MOR

14 (Model 3, Table 5). The somewhat smaller effect elevation had on MOR compared to MOE is in 15 accordance with the hypothesis stated in the introduction that elevation has a greater effect on 16 MOE than on MOR due to the greater effect of density on MOE compared to MOR (Vestøl et al. 17 2012). In a study of 14 of the sites Vestøl et al. (2016) found that density explained 68.2\% of the 18 site variance of MOR and $78.6 \%$ of the site variance of MOE. Besides density, the bending 19 properties are also influenced by other wood properties and defects, of which knots and fiber 20 deviations are the most important (Johansson 2003). These effects vary more within trees, 21 leading to a larger residual variance. According to Vestøl et al. (2012), knot diameter has a larger 22 effect on MOR than on MOE, suggesting that much of the within-tree variation in MOR can be 23 attributed to differences in knot size. This explains the differences in the distribution of the 
1 unexplained variances of density, MOE and MOR. It also explains why the effect of latitude was

2 significant only for density and not for the bending properties, and why site index was significant

3 only for density and MOE, not for MOR.

4

5 Within sites, the correlation between annual ring width and density is higher since there is no

6 additional effect of climate (Wilhelmsson et al. 2002). The negative effect of an increased

7 diameter growth on density, which is related to $\mathrm{DBH}$ and age, also has a significant negative

8 effect on bending properties. This effect is amplified by the additional effect of knot size, which

9 to a great extent is positively correlated with diameter growth (Høibø 1991). The effect of knot

10 size is related to large crowns and longer and thicker branches in dominant trees compared to

11 more suppressed trees (Moberg 2001, Vestøl and Høibø 2001). Since only trees with a DBH

12 greater than $20 \mathrm{~cm}$ were sampled, the trees from sites with a small average diameter were, on

13 average, more dominant than the trees sampled from stands with a greater-than-average $\mathrm{DBH}$.

14 This sampling effect may explain why DBH also explained some of the variance due to site.

16 The positive interaction effect between $\mathrm{LP}_{\text {rel }}$ and site index on density found in this extended

17 dataset of 17 sites (which also includes the three sites of Høibø et al. (2014)) fits with the results

18 of Høibø et al. (2014), who found density to increase with height above ground for the richest

19 site and decrease with height for the poorest site. The extended dataset shows a type of

20 interaction effect of $\mathrm{LP}_{\text {rel }}$ and DBH on density similar to the one described in Høibø et al. (2014).

21

22 The longitudinal variation in bending properties depends on the combined effect of density and

23 knot size. While the longitudinal variation in density is not consistent in Norway spruce (see e.g. 
1 Kuçera 1994, Hakkila 1966, Atmer and Thörnqvist 1982, Johansson 1992, Repola 2006, Jyske et

2 al. 2008), an increase in knot diameter together with increasing distance from the ground in the

3 lower part of the stem has been found to be a regular pattern (Mäkinen et al. 2003, Moberg 2001,

4 Colin and Houllier 1991, Wilhelmson et al. 2002). This pattern is a result of increased branch

5 longevity due to declines in stand density with age and the accumulated growth of branches in

6 the living part of the crown. Since the correlation with density is stronger for MOE and the effect

7 of knot size is stronger on MOR (Vestøl et al. 2012, Høibø et al. 2014), the different longitudinal

8 variations in density and knot size result in different longitudinal variations in MOE and MOR.

10 The effect of elevation is mainly climatic and it influences the relation between density and

11 annual ring width (Wilhelmsson et al. 2002). For MOE, the positive interaction effect between

12 elevation and longitudinal position (Model 2, Table 5), which shows that the effect of elevation

13 is greater for timber from butt logs than for timber from upper logs, follows the corresponding

14 interaction in the density model (Model 1, Table 5). The positive interaction with site index also

15 shows that the longitudinal variation in MOE in timber from lower site indices follows the same

16 pattern as the density variation with an increasing longitudinal position. For low site indices,

17 both the effect of knot size and the effect of density contribute to a vertical decrease in MOE.

18 However, in timber from higher site indices, there is a vertical increase in density, which is

19 positive for MOE, while the effect of knot size is the opposite. The contrary effects result in a

20 negligible longitudinal variation in MOE for higher site indices.

21

22 MOR is more strongly dependent on knot size than MOE is (Ranta-Maunus 2009). The greater

23 effect of $\mathrm{DBH}$ on MOR in timber from the upper part of trees from a higher site index might be 
1 due to a greater effect from knot diameter. In trees from stands with a higher site index, knot

2 diameter varies more in the longitudinal direction (Vestøl and Høibø 2001), and the greatest

3 difference between trees is found in the lower part of the living crown, where the thickest knots

4 are located. The smaller longitudinal variation in knot diameter on trees from lower site indices

5 makes the effect of knot size smaller and the effect of density correspondingly more important.

7 Site variance constituted a larger proportion for density than for the bending properties (Table 6).

8 The sites covered a wide geographical area and also a wide range of site indices, while the

9 silvicultural regime was not taken into account when choosing the sites. The sites appeared to

10 have relatively small differences in knot size but larger differences due to density. This may also

11 explain why relatively large proportions of the variance due to site were explained by variables

12 that are independent of silviculture, i.e. site index, latitude and elevation. However, for MOR a

13 relatively large reduction in variance between trees within a stand was achieved, as compared

14 with density and MOE (Table 5). This is probably due to the fact that the effect of knot diameter

15 is greater on MOR than on MOE (Ranta-Maunus 2009, Vestøl et al. 2012) and to a relatively

16 large variation in knot diameter between trees within stands and less variation between stands.

17 DBH within stands is usually well correlated with branch diameter (Loubère et al. 2004) because

18 dominant trees have longer and thicker branches than more suppressed trees (Moberg 2001,

19 Vestøl and Høibø 2001). $\mathrm{DBH}_{\text {rel }}$ was expected to describe the social position within stands, but it

20 turned out to be less important than DBH. This might in part be due to the sampling effect that

21 followed from only selecting trees with a DBH greater than $20 \mathrm{~cm}$. Density is more important for

22 MOE than for MOR (Vestøl et al. 2012), making variation in wood density between stands more 
1 important for MOE, and in particular for this material, which has a relatively large range in

2 elevation and latitude.

4 Liu et al. (2007) have presented models for MOE and MOR with a better fit for black spruce

5 timber from naturally grown forests in eastern Canada than we have obtained in this study. When

6 using only tree and site variables, their MOE model showed a substantially better RMSE than the

7 MOE model presented in our study, while the difference was small for the MOR models.

8 However, their models exhibited a poorer fit for the validation material for both MOE and MOR.

9 Several studies (Lei et al. 2005, Liu et al. 2007, Haartveit and Flæte 2002, Øvrum 2013) have

10 concluded that stem taper is an important variable when modelling MOE, MOR and grade yield.

11 However, in this study, stem taper (tree slenderness, H/DBH) was correlated with DBH, site

12 index, and elevation (Table 3), and was of minor importance compared to these variables. This is

13 probably related to the wide range of elevations, latitudes and site indices in this material.

15 In the present study, we included samples from a large range of elevations, latitudes and site

16 indices in order to cover the procurement area for most sawmills in Norway. One limitation of

17 the material is the lack of sites at higher elevations in the northernmost part of the study area, and

18 one should be cautious when using the models for timber from such areas. Considering the

19 distribution of site indices in Norway, where over $70 \%$ of the forest is found to have a site index

20 between 11 and 20, the study material represents timber used for structural purposes fairly well.

21 However, for modelling purposes it might have been better to have more sites with a higher site

22 index where the timber properties are more dependent on silvicultural regime. The models

23 showed small effects of site and tree variables that depend on silvicultural regime, but a much 
1 greater effect of site variables that depend on climate or other growth conditions. This might be

2 due to the small differences in silviculture among the sites.

4 The models show that the variability of the density and bending properties of Norway spruce

5 structural timber can in part be explained by geographical data and forest inventory data

6 including external tree measurements. The models were tested and showed a good fit for the

7 validation material. It can therefore be concluded that the models give reliable predictions for

8 density, MOE, and MOR within the range of the sampled material. The models explained major

9 parts of the site variances of all properties, whereas smaller parts of within tree variances were

10 explained. A substantial part of the between-tree variance in MOR was explained, while smaller

11 parts of the between-tree variance were explained for density and MOE. The models describe

12 both geographical variations and variations due to growth. Elevation, site index and latitude were

13 the most important site variables and $\mathrm{DBH}$ and age the most important tree variables. Since the

14 models describe substantial parts of the between-site variance they can be used to select stands

15 with timber that is suitable for higher strength classes. The models also describe some of the

16 variation within sites, and can be used for pre-sorting timber and to some extent to estimate

17 effects of silviculture on timber properties.

\section{Acknowledgements}

21 This study is part of the national project 'Tresterk', managed by the Norwegian Institute of

22 Wood Technology and supported by the Research Council of Norway under grant number

23 208085/I10, Fondet for Treteknisk Forskning, Skogtiltaksfondet and Norwegian forest industries. 
1 The authors are grateful to the forest owners and forest owners' associations for providing the

2 timber, and to Moelven Soknabruket AS, Begna Bruk AS and InnTre AS for processing the

3 timber. We also want to thank Sebastian Knutsen, Runa Stenhammer Aanerod, Friederike

4 Mennicke and Ludvig Fjeld for assisting in the lab.

\section{References}

Atmer, B., and Thörnqvist, T. 1982. The properties of tracheids in spruce (Picea abies Karst.) and pine (Pinus sylvestris L.). Swedish university of agricultural sciences, Reports No. 134.

Colin, F., and Houllier, F. 1991. Branchiness of Norway spruce in North-eastern France modelling vertical trends in maximum nodal branch size. Ann. Sci. For. 48(6): 679-693. doi: 10.1051/forest: 19910606

Foslie, M. 1985. Gran og sitka innplantet på Vestlandet. En undersøkelse over kvalitetfordeling og bearbeidingsegenskaper. Norsk treteknisk institutt. Meddelese 69.

Foslie, M., and Moen, K. 1968. Norsk granvirkes styrkeegenskaper. 1. Bøyestyrke, elastisitetsmodul og strekkstyrke målt på 3"x8" og 2"x4" [Strength properties of Norwegian Spruce. 1. Bending strength, modulus of elasticity and tensile strength tested on the structural sizes 3"x8" og 2"x4"]. vol 33. NTI, Oslo.

Gardiner, B., Leban, J. M., Auty, D., and Simpson, H. 2011. Models for predicting wood density of British-grown Sitka spruce. Forestry 0(0): 1-14. doi:10.1093/forestry/cpq050 
Gindl, W., Grabner, M., and Wimmer, R. 2000. The influence of temperature on latewood lignin content in treeline Norway spruce compared with maximum density and ring width. Trees 14(7), 409-414. doi:10.1007/s004680000057

Haartveit, E.Y. and Flæte, P.O. 2002. Mechanical properties of Norway spruce lumber from monocultures and mixed stands - modelling bending stiffness and strength using stand and tree characteristics. Poster presented at IUFRO Working Party S5.01-04 Workshop: Connection between Forest Resources and Wood Quality: Modelling approaches and simulation software, Harrison Hot Springs Resort, B.C., 8-15 September 2002. Edited by G. Nepveu.

Hakkila, P. 1966. Investigations on the basic density of Finnish pine, spruce and birch wood. Comm. Inst. For. Fenn. 61(5): 1-98.

Hautamäki S., Kilpeläinen H., Verkasalo E. 2013. Factors and models for the bending properties of sawn timber from Finland and North-Western Russia. Part I: Norway spruce. Baltic Forestry 19(1):106-119.

Høibø, O.A. 1991. The quality of wood of Norway spruce (Picea abies (L.) Karst) planted with different spacing. Ph.D. thesis, Department of Forestry, Agricultural University of Norway, Ås, Norway.

Høibø, O., and Vestøl, G.I. 2010. Modelling the variation in modulus of elasticity and modulus of rupture of Scots pine round timber. Can. J. For. Res. 40(4): 668-678.

Høibø, O., Vestøl, G.I., Fischer, C., Fjeld, L., and Øvrum, A. 2014. Bending properties and strength grading of Norway spruce: variation within and between stands. Can. J. For. Res. 44: 128-135. doi: 10.1139/cjfr-2013-0187 
Johansson, K. 1992. Effects of initial spacing on the stem and branch properties and graded quality of Picea abies (L.) Karst. Scand. J. For. Res. 7(1-4): 503-514. doi: $10.1080 / 02827589209382743$

Johansson, C.-J. 2003. Grading of timber with respect to mechanical properties. In Timber Engineering. Edited by S. Thelandersson and H.J. Larsen. John Wiley \& Sons, Ltd, Chichester, UK, pp. 23-43.

Jyske, T., Makinen, H., and Saranpaa, P. 2008. Wood density within Norway spruce stems. Silva Fenn. 42(3): 439-455.

Kellogg, R.M., and Kennedy, R.W. 1986. Implications of Douglas fir wood quality relative to practical end use. In Proceedings of a Symposium, Douglas-fir: Stand Management for the Future, Seattle, Wash, 18-20 June 1985. Edited by C.D. Oliver, D.P. Hanley, and J.A. Johnson. College of Forest Resources, University of Washington, Seattle, Wash. pp. 103-107.

Kollmann, F.F.P., Côté, W.A. 1968. Principles of Wood Science and Technology, vol 1. Springer Verlag, Berlin.

Kliger, R., Perstorper, M., and Johansson, G. 1998. Bending properties of Norway spruce timber. Comparison between fast- and slow-grown stands and influence of radial position of sawn timber. Ann. For. Sci. 55:349-358. doi: 10.1051/forest:19980306

Kuçera, B. 1994. A hypothesis relating to annual height increment to juvenile wood formation in Norway spruce. Wood and Fiber Science 26(1): 152-167

Lackner, R., and Foslie, M. 1988. Gran fra Vestlandet-Styrke och sortierung. Norwegian Institute of Wood Technology, Report 74. 
Lei, Y.C., Zhang, S.Y., and Jiang, Z. 2005. Models for predicting lumber bending MOR and MOE based on tree and stand characteristics in black spruce. Wood Sci. Technol. 39(1): 37-47. doi: 10.1007/s00226-004-0269-x.

Littell, R.C., Milliken, G.A., Stroup, W.W., Wolfinger, R.D., Schabenberger, O. 2006. SAS for mixed models. SAS Institute Inc., Cary, North Carolina.

Liu, C., Zhang, S.Y., Cloutier, A., and Rycabel, T. 2007. Modeling lumber bending stiffness and strength in natural black spruce stands using stand and tree characteristics. For. Ecol. Manage. 242(2): 648-655. doi:10.1016/j.foreco.2007.01.077

Loubère, M., Saint-André, L., Hervé, J.C., and Vestøl, G.I. 2004. Relationships between stem size and branch basal diameter variability in Norway spruce (Picea abies (L.) Karsten) from two regions of France. Ann. For. Sci. 61(6), 525-535. doi: 10.1051/forest:2004047

Lukacevic, M., Füssl, J., Eberhardsteiner, J. 2015. Discussion of common and new indicating properties for the strength grading of wooden boards. Wood Sci. Technol. 49(3): 551-576. doi:10.1007/s00226-015-0712-1 10.1007/s00226-015-0712-1

Maguire, D.A., Johnston, S.R., and Cahill, J. 1999. Predicting branch diameters on second growth Douglas-fir from tree level descriptors. Can. J. For. Res. 29(12): 1829-1840. doi:10.1139/cjfr-29-12-1829.

Mäkinen, H., Ojansuu, R., Sairanen, P., and Yli-Kojola, H. 2003. Predicting branch characteristics of Norway spruce (Picea abies (L.) Karst.) from simple stand and tree measurements. Forestry 76(5): 525-546. doi:10.1093/forestry/76.5.525 
Mäkinen, H., and Colin, F. 1998. Predicting branch angle and branch diameter of Scots pine from usual tree measurements and stand structural information. Can. J. For. Res. 28(11):16861696. doi:10.1139/cjfr-28-11-1686

Moberg, L. 2001. Models of internal knot diameter for Picea abies. For. Ecol. Manage. 147(2-3), 123-138. doi:10.1016/S0378-1127(00)00471-0.

Moore, J.R., Lyon, A.J., Searles, G.J., Lehneke, S.A., Ridley-Ellis, D.J. 2013. Within- and between-stand variation in selected properties of Sitka spruce sawn timber in the UK: implications for segregation and grade recovery. Ann. For. Sci. 70(4): 403-415. doi:10.1007/s13595-013-0275-y.

Nagoda, L. 1985. Strength properties of Norway spruce (Picea abies (L.) Karst.) from Northern Norway tested on timber in structural sizes. Meddelelser 38(17) fra Norsk Institutt for Skogforskning (Norway).

Pape, R. 1999. Effects of thinning on wood properties of Norway spruce on highly productive sites. Ph.D. thesis, Swedish university of agricultural sciences, Uppsala, Sweden.

Persson, A. 1975. Spacing and the quality of sawn timber in Scots Pine. Sver. skogsvårdsförb. tidskr 73: 433-441.

Ranta-Maunus, A. (ed) (2009) Strength of European timber. Part 1. Analysis of growth areas based on existing test results. VTT Publication 706, VTT, Finland.

Repola, J. 2006. Models for vertical wood density of Scots pine, Norway spruce and birch stems, and their application to determine average wood density. Silva Fennica 40(4): 673.

Standard Norge 2009. Structural timber - Strength classes. Norsk Standard NS-EN338. 
Standard Norge 2010a. Structural timber - Determination of characteristic values of mechanical properties and density. Norsk Standard NS-EN 384.

Standard Norge 2010b. Timber structures - Structural timber and glued laminated timber Determination of some physical and mechanical properties. Norsk Standard NS-EN 408.

Stapel, P., and van de Kuilen, J.W.G. 2013. Effects of grading procedures on the scatter of characteristic values of European grown sawn timber. Materials and structures 46(9): 1587-1598. doi: $10.1617 /$ s1 1527-012-9999-7

Steiger, R. and Arnold, M. 2009. Strength grading of Norway spruce structural timber: revisiting property relationships used in EN 338 classification system. Wood Sci Technol 43(3-4): 259278. doi: 10.1007/s00226-008-0221-6.

Tveite, B. 1977. Site-index curves for Norway Spruce (Picea abies (L.) Karst.). Norwegian Research Forest Institute Rapport 33(1).

Vestøl, G.I., Fischer, C., Høibø, O., and Øvrum, A. 2016. Between- and within site variation of density and bending properties of Picea abies structural timber from Norway. Scand. J. For. Res. doi: $10.1080 / 02827581.2016 .1174733$

Vestøl, G.I., Høibø, O., Langsethagen, K.G., Skaug, E., and Skyrud, R.E.A. 2012. Variability of density and bending properties of Picea abies structural timber. Wood Material Science and Engineering 7(2): 76-86. doi:10.1080/17480272.2012.662698

Vestøl, G.I., and Høibø, O.A. 2001. Prediction of knot diameter in Picea abies (L.) Karst. Holz Roh. Werkst. 59(1-2): 129-136. doi: 10.1007/s001070050484 
Wilhelmsson, L. 2001. Characterisation of wood properties for improved utilization of Norway spruce and Scots pine. Ph.D. thesis, Swedish University of Agricultural Sciences, Uppsala, Sweden.

Wilhelmsson, L., Arlinger, J., Spångberg, K., Lundqvist, S.-O., Grahn, T., Hedenberg, Ö., and Olsson, L. 2002. Models for predicting wood properties in stems of Picea abies and Pinus sylvestris in Sweden. Scand. J. For. Res. 17(4): 330-350.

Zobel, B. J., and Van Buijtenen, J. P. 1989. Wood variation-its causes and control. Springer Verlag, Berlin.

Øvrum, A. 2013. In-forest assessment of timber stiffness in Norway spruce (Picea abies (L.)

Karst.). Eur. J. Wood. Wood. Prod. 71(4): 429-435. doi: 10.1007/s00107-013-0694-3. 


\section{Tables}

Table 1. Geographical and forest inventory data.

\begin{tabular}{lcccccrr}
\hline \multicolumn{1}{l}{ Site No. } & N trees & Lat $(\mathrm{N})$ & Lon $(\mathrm{E})$ & Elev & SI & mean Age & mean DBH \\
\hline \multicolumn{1}{l}{ Modelling material } & & & & & & \\
01 & 13 & 58.2889 & 8.1957 & 170 & 14 & 138 & 33.0 \\
02 & 15 & 58.5288 & 8.4627 & 210 & 20 & 66 & 29.9 \\
04 & 15 & 59.8567 & 10.3284 & 380 & 17 & 76 & 27.9 \\
05 & 14 & 60.0383 & 9.1125 & 700 & 11 & 153 & 33.2 \\
06 & 14 & 60.2555 & 8.9446 & 800 & 11 & 124 & 26.6 \\
07 & 15 & 60.5320 & 11.3701 & 370 & 20 & 58 & 24.0 \\
09 & 15 & 60.6618 & 10.8852 & 220 & 20 & 104 & 29.0 \\
11 & 15 & 61.3102 & 10.2391 & 630 & 14 & 120 & 29.4 \\
14 & 15 & 63.6511 & 10.9141 & 100 & 14 & 125 & 28.2 \\
15 & 15 & 59.2185 & 11.2637 & 80 & 24 & 80 & 24.6 \\
16 & 15 & 59.5469 & 10.8980 & 102 & 11 & 161 & 21.2 \\
Validation material & & & & & & \\
03 & 15 & 59.6401 & 10.4487 & 150 & 26 & 49 & 26.9 \\
08 & 15 & 60.6371 & 9.7993 & 544 & 11 & 108 & 26.3 \\
10 & 14 & 61.0632 & 9.5403 & 845 & 14 & 91 & 29.2 \\
12 & 15 & 62.7471 & 9.9898 & 470 & 14 & 128 & 27.6 \\
13 & 15 & 63.3521 & 10.2455 & 150 & 17 & 119 & 31.6 \\
17 & 15 & 59.5411 & 10.8937 & 115 & 17 & 157 & 28.3 \\
\hline
\end{tabular}


Table 2. Variables used for modelling.

\begin{tabular}{|c|c|c|}
\hline Variables & Abb. & Unit \\
\hline \multicolumn{3}{|l|}{ Site variables } \\
\hline Site index, dominant height at age 40 & SI & $\mathrm{m}$ \\
\hline Elevation & Elev & m.a.s. \\
\hline Latitude & Lat & \\
\hline Basal area & BA & $\mathrm{m}^{2} \mathrm{ha}^{-1}$ \\
\hline \multicolumn{3}{|l|}{ Tree variables } \\
\hline Age & Age & years \\
\hline Diameter at breast height, over bark & $\mathrm{DBH}$ & $\mathrm{mm}$ \\
\hline Ratio of DBH of the sample trees to the mean DBH of the site & $\mathrm{DBH}_{\text {rel }}$ & \\
\hline Tree height & $\mathrm{H}$ & $\mathrm{dm}$ \\
\hline Tree slenderness & $\mathrm{H} / \mathrm{DBH}$ & $\mathrm{dm} \mathrm{mm} \mathrm{m}^{-1}$ \\
\hline Ratio of DBH to the age of the trees & $\mathrm{DBH} /$ Age & $\mathrm{mm}$ \\
\hline Height to the whorl where live branches covered half of the circumference & $\mathrm{KH}_{180}$ & $\mathrm{dm}$ \\
\hline Height to the whorl where the live branches covered the whole circumference & $\mathrm{KH}_{360}$ & $\mathrm{dm}$ \\
\hline Relative longitudinal position of the board in the tree & $\mathrm{LP}_{\text {rel }}$ & \\
\hline \multicolumn{3}{|l|}{ Board variable } \\
\hline Modulus of elasticity & $\mathrm{MOE}_{12}$ & $\mathrm{kN} \mathrm{mm} \mathrm{m}^{-2}$ \\
\hline Modulus of rupture/ bending strength & $\mathrm{MOR}_{12}$ & $\mathrm{~N} \mathrm{~mm} \mathrm{~m}^{-2}$ \\
\hline Density & $\rho_{12}$ & $\mathrm{~kg} \mathrm{~m}^{-3}$ \\
\hline
\end{tabular}


Table 3. Correlation matrix for tested variables.

\begin{tabular}{|c|c|c|c|c|c|c|c|c|c|c|c|c|c|}
\hline & SI & BA & Elev & Lat & DBH & $\mathrm{H}$ & Age & DBH/Age & $\mathrm{DBH}_{\text {rel }}$ & $\mathrm{H} / \mathrm{DBH}$ & $\mathrm{KH}_{180}$ & $\mathrm{KH}_{360}$ & $\mathrm{LP}_{\text {rel }}$ \\
\hline SI & 1 & 0.78 & $-0,53$ & $-0,23$ & $-0,01$ & 0.47 & $-0,67$ & 0.71 & $-0,05$ & 0,49 & 0,46 & 0,40 & 0,06 \\
\hline $\mathrm{BA}$ & & 1 & -0.36 & -0.13 & -0.12 & 0.29 & -0.58 & 0.56 & $-0,07$ & 0,43 & 0,41 & 0,31 & 0.03 \\
\hline Elev & & & 1 & 0,14 & $-0,07$ & -0.54 & 0,04 & -0.16 & $-0,13$ & $-0,47$ & $-0,53$ & $-0,55$ & $-0,06$ \\
\hline Lat & & & & 1 & $-0,07$ & -0.11 & 0,13 & -0.25 & $-0,13$ & $-0,05$ & $-0,12$ & $-0,07$ & $-0,02$ \\
\hline DBH & & & & & 1 & 0.60 & 0,29 & 0.27 & 0,87 & $-0,58$ & 0,18 & 0,23 & 0,11 \\
\hline $\mathrm{H}$ & & & & & & 1 & 0,08 & 0.27 & 0,49 & 0,28 & 0,70 & 0,72 & 0.13 \\
\hline Age & & & & & & & 1 & -0.78 & 0,31 & $-0,27$ & 0,08 & 0,15 & 0,01 \\
\hline DBH/Age & & & & & & & & 1 & 0,22 & $-0,04$ & 0,05 & $-0,01$ & 0.05 \\
\hline $\mathrm{DBH}_{\text {rel }}$ & & & & & & & & & 1 & $-0,55$ & 0,12 & 0,13 & 0,10 \\
\hline $\mathrm{H} / \mathrm{DBH}$ & & & & & & & & & & 1 & 0,51 & 0,45 & -0.01 \\
\hline $\mathrm{KH}_{180}$ & & & & & & & & & & & 1 & 0,89 & 0.11 \\
\hline $\mathrm{KH}_{360}$ & & & & & & & & & & & & 1 & 0.11 \\
\hline $\mathrm{LP}_{\text {rel }}$ & & & & & & & & & & & & & 1 \\
\hline
\end{tabular}


Table 4. Number of observations, minimum, maximum, mean values, and standard deviations of density and bending properties of the measured boards.

\begin{tabular}{|c|c|c|c|c|c|}
\hline & $\mathrm{N}$ & $5 \%$ percentile & $95 \%$ percentile & mean & Std dev \\
\hline \multicolumn{6}{|l|}{ Modelling material } \\
\hline $\operatorname{MOE}_{12}\left(\mathrm{kN} \mathrm{mm}^{-2}\right)$ & 984 & 9.45 & 18.2 & 13.5 & 2.80 \\
\hline $\mathrm{MOR}_{12}\left(\mathrm{~N} \mathrm{~mm}^{-2}\right)$ & 984 & 30.3 & 70.3 & 49.6 & 12.2 \\
\hline Density, $\rho_{12}\left(\mathrm{~kg} \mathrm{~m}^{-3}\right)$ & 984 & 389 & 561 & 464 & 52.4 \\
\hline \multicolumn{6}{|l|}{ Validation material } \\
\hline $\operatorname{MOE}_{12}\left(\mathrm{kN} \mathrm{mm}^{-2}\right)$ & 567 & 8.74 & 19.0 & 13.1 & 2.96 \\
\hline $\mathrm{MOR}_{12}\left(\mathrm{~N} \mathrm{~mm}^{-2}\right)$ & 567 & 27.9 & 69.7 & 48.2 & 12.8 \\
\hline Density, $\rho_{12}\left(\mathrm{~kg} \mathrm{~m}^{-3}\right)$ & 567 & 370 & 562 & 455 & 54.1 \\
\hline \multicolumn{6}{|l|}{ All } \\
\hline $\operatorname{MOE}_{12}\left(\mathrm{kN} \mathrm{mm}^{-2}\right)$ & 1551 & 9.13 & 18.4 & 13.4 & 2.86 \\
\hline $\mathrm{MOR}_{12}\left(\mathrm{~N} \mathrm{~mm}^{-2}\right)$ & 1551 & 29.7 & 70.2 & 49.1 & 12.4 \\
\hline Density, $\rho_{12}\left(\mathrm{~kg} \mathrm{~m}^{-3}\right)$ & 1551 & 382 & 562 & 460 & 53.1 \\
\hline
\end{tabular}


Table 5. Models for density, $\mathrm{MOE}_{12}$, and $\mathrm{MOR}_{12}$.

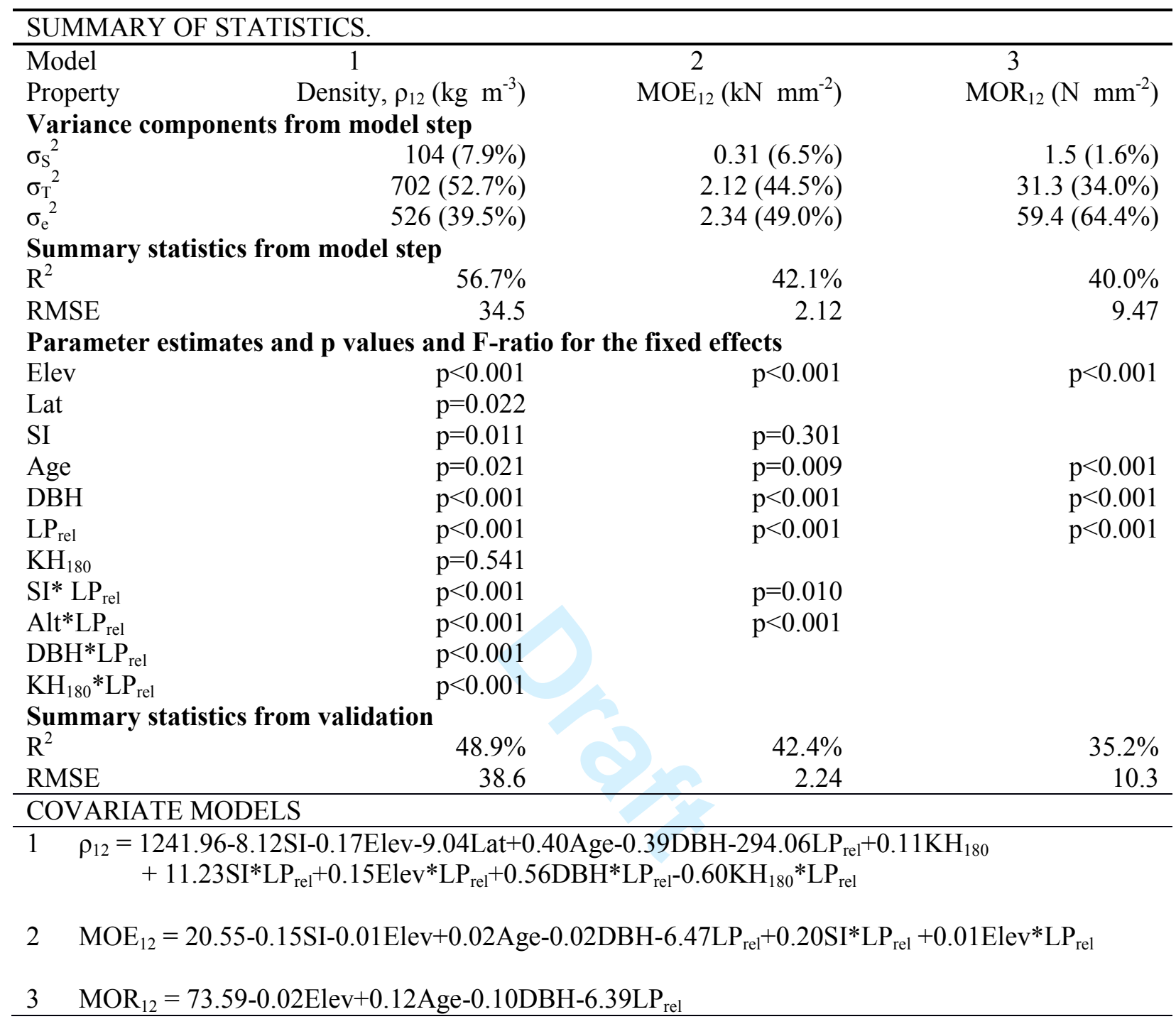


Table 6. Variance component model for density, $\mathrm{MOE}_{12}$, and MOR 12 .

\begin{tabular}{llrr}
\hline & $\sigma_{\mathrm{S}}{ }^{2}$ & $\sigma_{\mathrm{T}}{ }^{2}$ & \multicolumn{1}{c}{$\sigma_{\mathrm{e}}{ }^{2}$} \\
\hline Density, $\rho_{12}$ & $1576(51.5 \%)$ & $830(27.1 \%)$ & $655(21.4 \%)$ \\
$\mathrm{MOE}_{12}$ & $2.91(35.5 \%)$ & $2.86(34.8 \%)$ & $2.44(29.7 \%)$ \\
$\mathrm{MOR}_{12}$ & $32.1(20.6 \%)$ & $63.5(40.7 \%)$ & $60.6(38.8 \%)$ \\
\hline
\end{tabular}

1 
Figures

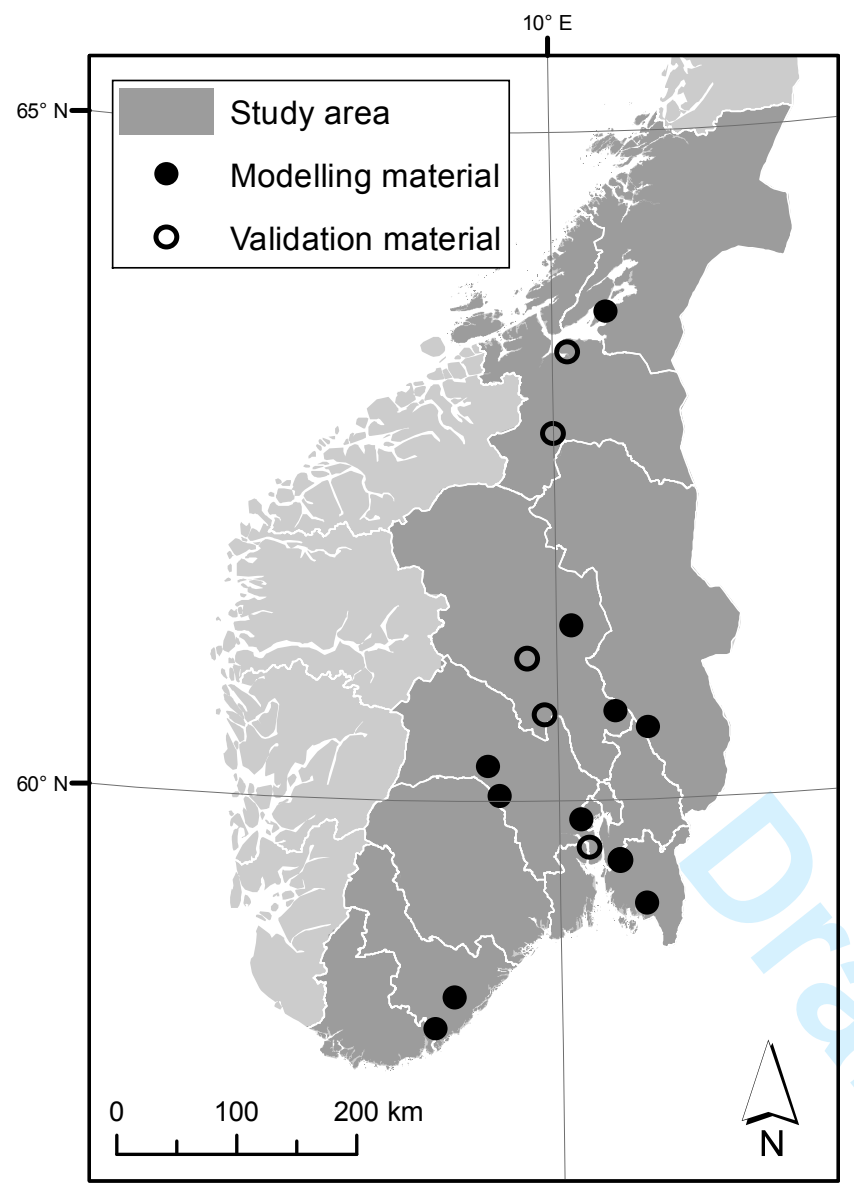

Figure 1. Sampling areas in Southern Norway, Eastern Norway and Trøndelag. 


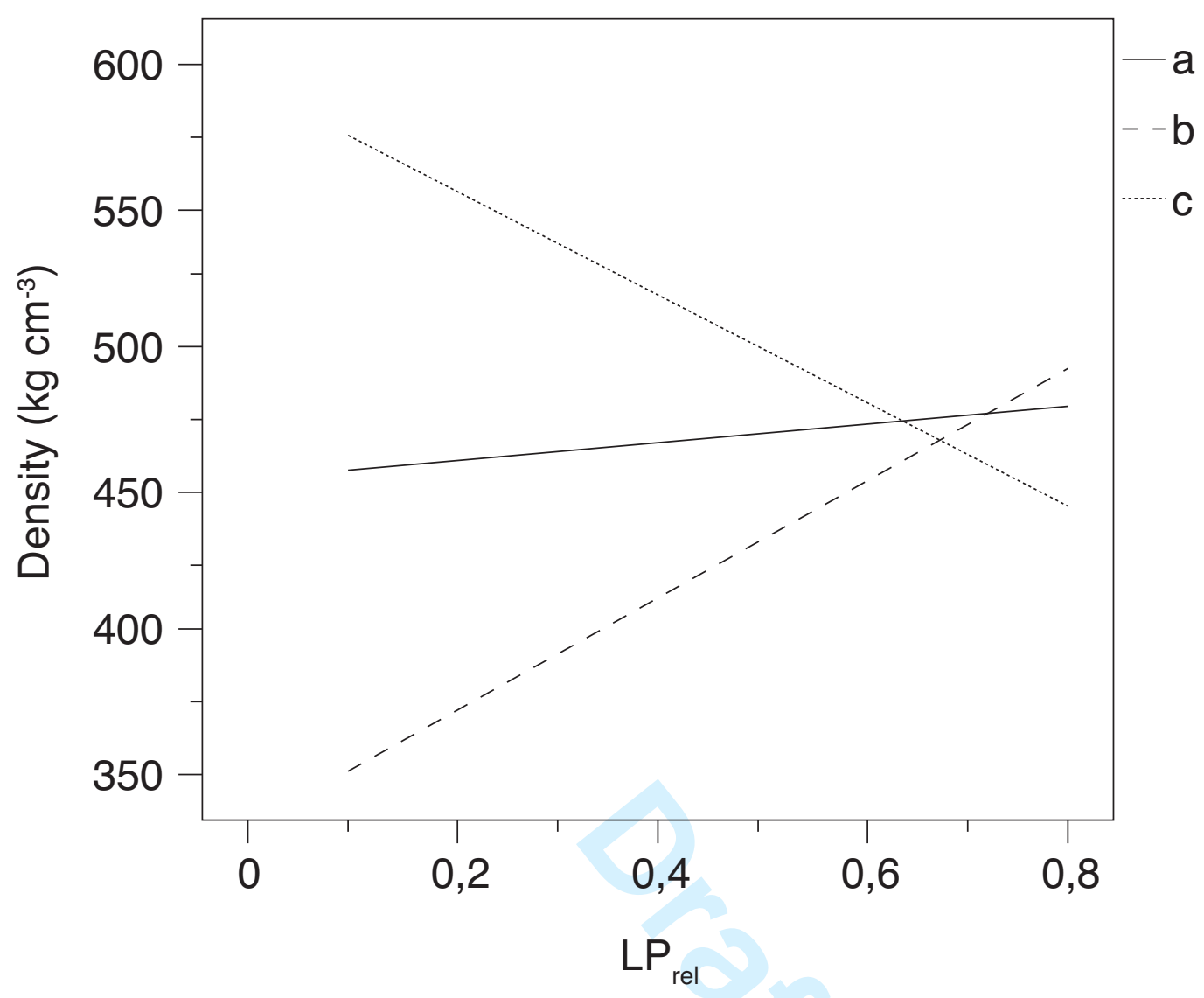

Figure 2. Predicted relationships of wood density to longitudinal position $\left(\mathrm{LP}_{\text {rel }}\right)$, as influenced by site index, elevation, $\mathrm{DBH}$, and $\mathrm{KH}_{180}$ : Line a) for mean values of the fixed effects, line b) for big trees with small $\mathrm{KH}_{180}$ at the highest realistic site index at high elevation and line c) for small trees with large $\mathrm{KH}_{180}$ at low site index at low elevation. 


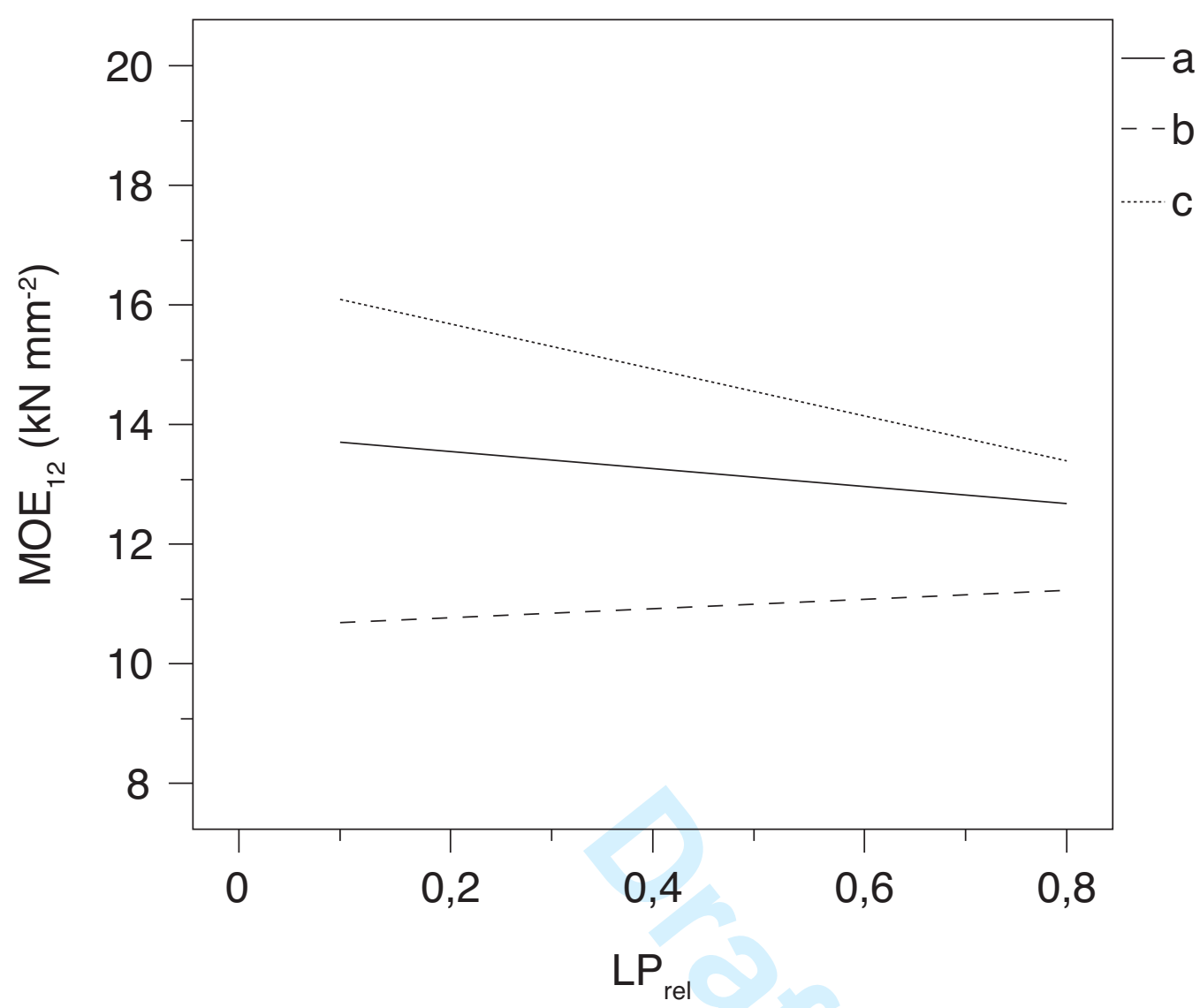

Figure 3. Predicted relationships of $\mathrm{MOE}_{12}$ to longitudinal position $\left(\mathrm{LP}_{\text {rel }}\right)$, as influenced by site index and elevation: Line a) for mean values of the fixed effects, line b) for trees at the highest realistic site index at high elevation and line c) for trees at low site index and low elevation. 


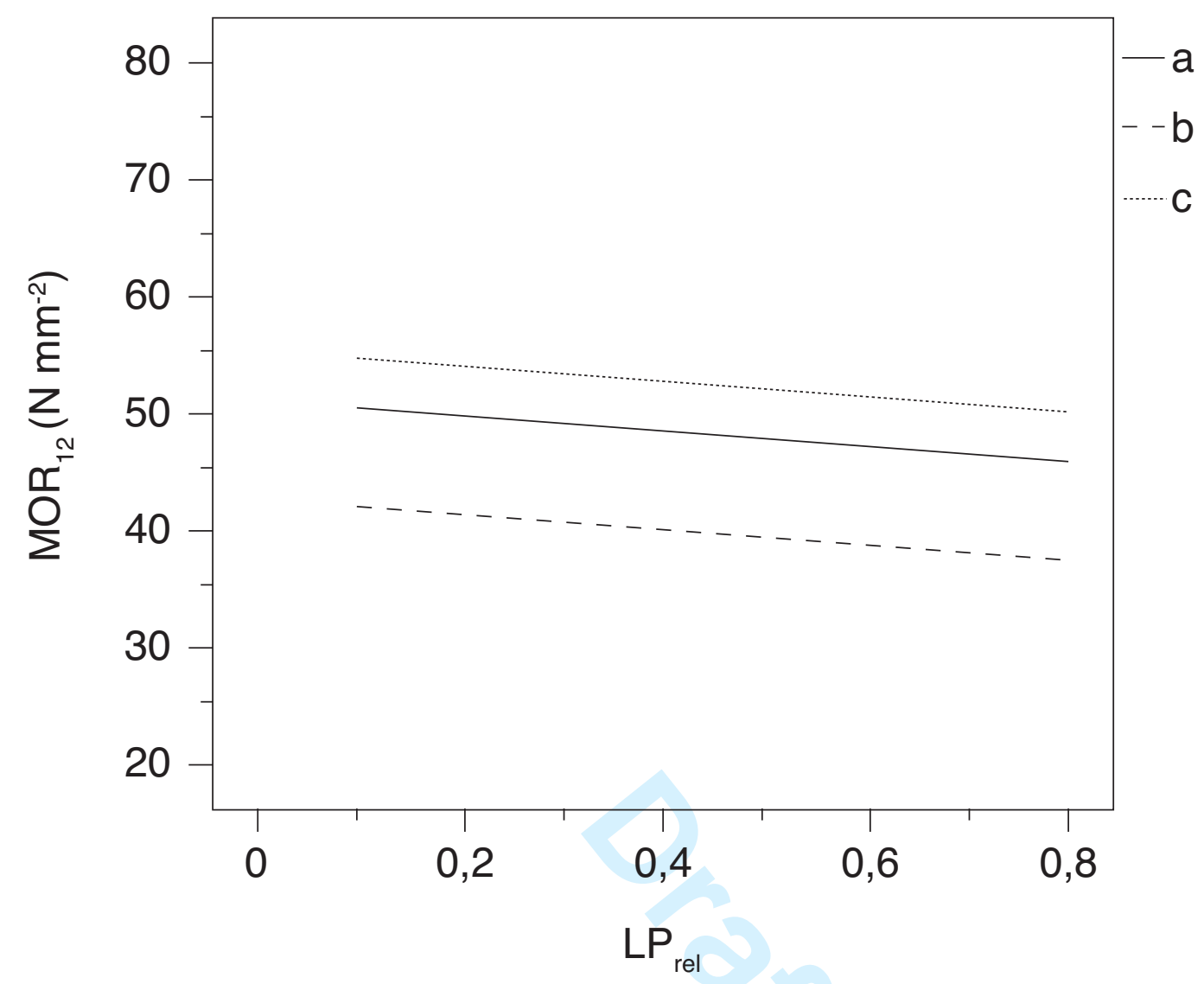

Figure 4. Predicted relationship of $\mathrm{MOR}_{12}$ to longitudinal position ( $\left.\mathrm{LP}_{\text {rel }}\right)$, as influenced by elevation: Line a) for mean values of the fixed effects, line b) for trees at high elevation and line c) for trees at low elevation. 